\title{
SOCIAL AND ECONOMIC PROCLIVITY OF SOCIAL ENTREPRENEURS: DIMENSIONS, MEASUREMENT, AND VALIDATION
}

\author{
ROBIN STEVENS \\ University College Ghent, Ghent University \\ Voskenslaan 270 \\ 9000 Ghent, Belgium \\ NATHALIE MORAY \\ University College Ghent, Ghent University
}

\begin{abstract}
Social entrepreneurs are argued to have a 'dominant social goal', using revenue streams from the market as a means to support their mission. However, the extent to which social entrepreneurs adhere to socially or economically oriented goals is largely treated as a black box. Performing higher order confirmatory factor analysis on a well defined sample of social enterprises ( $\mathrm{N} 270$ ), this paper develops and validates measures for gaining insight in the relative importance of the "social" and "economic" proclivity of social entrepreneurs, which are operationalized as aggregated constructs encompassing three conceptual dimensions: work values, organizational identity, and responsibility.
\end{abstract}

\section{INTRODUCTION}

There is an increasing interest in social entrepreneurs, typically referred to as firms tackling social problems and catalyzing social transformation. Social entrepreneurship is argued to be "entrepreneurship with an embedded social purpose" (Christie \& Honig, 2006; Peredo \& Chrisman, 2006; Peredo \& McLean, 2006), "at least partially sustainable through trading" (Birch \& Whittam, 2008; Chell, 2007; DTI, 2007; Haugh, 2007; Peredo \& Chrisman, 2006; Tracey \& Jarvis, 2007), and not being limited to a particular judicial / organizational form (Birch \& Whittam, 2008; Chell, 2007; Mair \& Marti, 2006).

Essentially, social entrepreneurs are argued to place higher value on the creation of social value and can vary in their ambition for economic value creation which is generally seen as a necessary condition to ensure financial viability (Dorado, 2006; Schuler \& Cording, 2006). In line with this, authors stress that social enterprises want to realize explicit social objectives and are limited in their profit distribution (Defourny \& Nyssens, 2008; DTI, 2007; Vidal, 2005) where profit is seen as a resource to serve a social goal (Haugh, 2007). This raises the question of the degree to which social entrepreneurs adhere to a social purpose and how this is balanced with economic - market oriented goals. As Mair \& Marti (2006: 39) put it: 'The main difference between entrepreneurship in the business sector and social entrepreneurship lies in the relative priority given to social wealth creation versus economic wealth creation.' To date however, empirical research in the field of social entrepreneurship seems to focus on 'good practices' of 'leading social entrepreneurs' that are seen as 'change makers' (Sharir \& Lerner, 2006; Van Slyke $\&$ Newman, 2006). The 'social' in social entrepreneurship is largely taken for granted, suggesting homogeneity in their 'social' manifestation. 
Building on established theoretical constructs, this paper develops a number of measures that can potentially contribute to our understanding of the relative importance of 'social' and 'economic' goals. More specifically, we sent a standardized survey to a well defined sample of social enterprises and performed confirmatory factor analysis (CFA) to assess the reliability and (construct) validity (N 270).

The remainder of the paper is structured as follows. We start with a succinct overview of the social entrepreneurship literature. We then explain the constructs we selected that can provide insight in the 'social proclivity' and 'economic proclivity' of social entrepreneurs. Next, we discuss the cross-sectional survey design. In the results section we discuss the reliability and validity of the measures and the extent to which they relate to the higher order constructs. Finally, suggestions for further research are articulated.

\section{THE 'SOCIAL’ IN SOCIAL ENTREPRENEURSHIP}

There is a general consensus that social entrepreneurship or "entrepreneurial activity that primarily serves a social objective" has been on the rise in recent decades (Austin, Stevenson, \& Wei-Skillern, 2006; Peredo \& Chrisman, 2006; Peredo \& McLean, 2006). More specifically, social entrepreneurship in general and the social enterprise movement in particular is seen as a response to diminishing government involvement in the economy and society (e.g., Nicholls, 2006; Sharir \& Lerner, 2006). As such, it originated from the non-for-profit sector (Dees, 1998; Harris, Sapienza, \& Bowie, 2009; Mort, Weerawardena, \& Carnegie, 2003; Weerawardena \& Mort, 2006) and extended rapidly to the private and public sector (Johnson, 2000). This paper defines social entrepreneurship as "entrepreneurship with an embedded social purpose" (Christie \& Honig, 2006), "at least partially sustainable through trading” (Birch \& Whittam, 2008; Chell, 2007; DTI, 2007; Haugh, 2007; Peredo \& Chrisman, 2006; Tracey \& Jarvis, 2007), and not being limited to a particular judicial / organizational form (Birch \& Whittam, 2008; Chell, 2007; Mair \& Marti, 2006).

Social entrepreneurs are argued to share two dominant characteristics: the focus on a 'social mission' or 'the creation of social value' (Austin et al., 2006; Dorado, 2006; Nyssens, 2006; Peredo \& McLean, 2006) and the sustainability of the organization through trading (Birch \& Whittam, 2008; Chell, 2007; Di Domenico, Haugh, \& Tracey, forthcoming; DTI, 2007; Strothotte \& Wüstenhagen, 2005; Tracey \& Jarvis, 2007). As for the focus on the social mission, authors agree that profit making is typically not the primary purpose of social entrepreneurs (Johnstone \& Lionais, 2004; Peredo \& Chrisman, 2006). Peredo and Chrisman (2006) speak of an 'array of aims', where profit is seen as a resource to serve a social goal. Further, the enterprising character prevails in social ventures with several scholars arguing that trading is at the core of social entrepreneurship (e.g., Tracey \& Jarvis, 2007). From this perspective, social enterprises share 'a continuous activity, producing and selling goods and/or services'(Nyssens, 2006).

Combining both characteristics, social entrepreneurs have a dual social and financial objective (Di Domenico et al., forthcoming; Dorado, 2006; Haugh, 2007; Moss, Short, Payne, \& Lumpkin, forthcoming; Thompson \& Doherty, 2006; Zahra, Gedajlovic, Neubaum, \& Shulman, 2009) that guides their managerial decision-making and is commonly referred to as the "double bottom line" (Dees \& Anderson, 2002; Dorado, 2006; Grimes \& Victor, 2009). Social entrepreneurial organizations are unique in their attempts to combine social and financial motives (Grimes \& Victor, 2009). As a result, authors (e.g., Grimes \& Victor, 2009; Peredo \& 
McLean, 2006; Townsend \& Hart, 2008; Zahra et al., 2009) have acknowledged a continuum of possibilities, with varying degrees of importance attached to the social goals. Clearly, the extent to which a firm adheres to a social purpose is often a matter of relative priority, where goals related to profit realization on one hand and social value on the other often interplay (Desa, 2007; Mair \& Marti, 2006; Peredo \& McLean, 2006).

Building on the generally accepted theoretical assumption that social entrepreneurs attach more importance to the social - using revenue / profit streams to support the mission - this paper aims at developing and validating measures for exactly capturing the relative importance of the 'social' and 'economic" proclivity in a social entrepreneurship context.

\section{UNDERSTANDING 'SOCIAL AND ECONOMIC PROCLIVITY'}

To further our understanding of how social entrepreneurs value the 'social' and 'economic' in their organizations, we searched five high impact management journals (Furrer, Thomas, \& Goussevskaia, 2008) on the web of science in search for theoretical constructs that offer opportunities for operationalization in measures (i.e., strategic management journal, academy of management journal, academy of management review, administrative science quarterly, and organization science). A total of 207 articles were identified using keywords (e.g., 'mission', 'identity', 'corporate social performance') in the title and topic field (Geyskens, Krishnan, Steenkamp, \& Cunha, 2009; Shepherd \& Wiklund, 2009). From these papers we selected three theoretical constructs which are informative on the social and economic proclivity of the organization, operationalized and empirically validated, published in top-tier management journals and theoretically validated. We discuss subsequently the constructs "organizational identity", "work values", and "responsibility".

Researchers define organizational identity as members' shared perceptions about their organization's central, distinctive, and enduring qualities (Brickson, 2007; Dutton \& Dukerich, 1991; Dutton, Dukerich, \& Harquail, 1994; Dyer \& Whetten, 2006; Fiol, 1991, 2001; Foreman \& Whetten, 2002). Basically, organizational identity is the answer to the question 'who are we'? Many organizations are hybrids composed of multiple identities. In this context Foreman and Whetten (2002) define organizational identification in terms of multiple and competing identities: a normative system, emphasizing traditions and symbols, internalization of an ideology and altruism, and a utilitarian system, characterized by economic rationality, maximization of profits and self-interest. These concepts can potentially inform us about the 'social and economic proclivity' of an organization.

Work values refer to what a person wants out of work in general and are guiding principles for evaluating work outcomes and settings and for choosing among different work alternatives (Ros, Schwartz, \& Surkiss, 1999). Thus, values affect decision making (Judge \& Bretz, 1992; Mumford, Helton, Decker, Connelly, \& Van Doorn, 2003). Further, personal characteristics in general (Cambra-Fierro, Hart, \& Polo-Redondo, 2008; Lepoutre \& Heene, 2006; Spence \& Rutherfoord, 2003) and work values of owners/managers in particular are argued to be a key factor in socially responsible business practice in SMEs (Murillo \& Lozano, 2006). A key dimension that informs us on the social orientation of an individual, is his level of 'other' regarding and 'self' regarding values (Agle, Mitchell, \& Sonnenfeld, 1999). In other words, to what extent is behavior ultimately self-interested or do individuals act in ways that benefit others, even to their own disadvantage? As a result, the level of self interest potentially captures the social proclivity of the organization. 
Socially responsible business practice implies that there is a responsibility of firms beyond their wealth generating function (Aguilera, Rupp, Williams, \& Ganapathi, 2007; Barnett, 2007). Carroll's (1979) presents a continuum on which firms can be positioned in terms of what they consider as their responsibility. More specifically, the author suggests four stances, representing increasing levels of social engagement. The first 'social' responsibility of business is economic in nature: the production of goods or the delivery of services society expects and sell them at a profit. Second, a business has to fulfill its economic mission within the framework of legal requirements. Next, ethical responsibilities refer to society's expectations over and above legal requirements which are considered to be intrinsically "good". Finally, the "discretionary" social activities are of a non-enforced, rather philanthropic nature referring to those responsibilities for which society has no clear-cut message for business. Gaining insight in the extent to which firms fulfill their social responsibilities, informs us on the social proclivity of the organization.

In summary, we purpose that social proclivity is an aggregated construct (Edwards, 2001) consisting out of the constructs of normative identity, other regarding values, and social orientation whereas economic proclivity is a aggregated construct consisting of the constructs of utilitarian identity, self-regarding values, and economic orientation. Further, we ultimately expect that social and economic proclivity are negatively related to each other.

\section{METHODOLOGY}

Building on the theoretical constructs, we develop measures to capture the identity, the degree of responsibility, and the importance of work values. Collecting data via a survey to the directors of a well defined sample of social enterprises, we use confirmatory factor analysis to assess the reliability and validity of each of the constructs and to determine whether or not they pertain to the same higher order constructs.

\section{Population and sample}

We selected four strata with organizations that are generally considered as being to some extent driven by social goals. Integration enterprises want to create temporary or long-term employment for this specific target population through productive activity. We listed the organizations of four social investors which they financed between 2004 and 2007 as a stratum. 'Vennootschap met Sociaal Oogmerk (VSO)' is a special Belgian judicial statue for enterprises with a social objective. We listed all VSOs in Flanders in 2007 as a third stratum. Finally, we merged two existing lists of cooperatives: Coopkracht and VOSEC are two Flemish institutions who unite cooperatives on their mission and values of people-planet-profit. After removing overlaps between the strata we calculated a total valid $\mathrm{N}(\mathrm{N}=484)$. Next to social and economic proclivity measures, we collected data on the number of integration employees, start-up capital, age and judicial form. We collected financial data from the annual financial statements such as (e.g., turn-over, accumulated profit,...) To maximize response rate we made several follow-up calls resulting in a total response of 270 social entrepreneurs (response rate of $56 \%$ ).

\section{Measures}


To measure the extent to which the social ventures adhere to a normative and utilitarian identity, we use the operationalization of Foreman and Whetten (2002). We included 4 items that represent the utilitarian identity (e.g., importance of price of products or services) and 4 items that represent the normative identity (e.g., social relationships with other members). All the items were measured on ordinal scales ranging from 1 (completely disagree) to 7 (completely agree). Based on the measurement instrument of Rokeach (1972), Agle et al. (1999) constructed a measure capturing the level of 'self-interest' versus 'other-regarding' interest. The authors developed 7 items of which 3 items represent self-interested values and 4 items other-regarding values. To capture the corporate orientation towards social responsibility we use the measure of Aupperle (1985). We asked respondents to allocate four times 10 points among four items representing the four areas of responsibility.

\section{DATA ANALYSIS}

The goal of our data-analyses is to assess the reliability and validity of the measures and assess the existence of higher order constructs 'social proclivity' and 'economic proclivity'. To minimize potential interpretational confounding, we established the validity of the measurement model before testing the structural model (Hair, Black, Babin, Anderson, \& Tatham, 2006).

\section{Model fit and construct validity}

We used a higher order CFA to test the validity of our measurement instrument. Because the variables of our model were all manager-rated and collected in the same survey instrument, we had to address an important concern prior to model building: common method variance. Although the procedure has some limitations (Podsakoff, MacKenzie, Lee, \& Podsakoff, 2003), we conducted Harman's single-factor test to address this concern and we assessed the risk of common method bias by using principal component analysis on all survey measures (Konrad \& Linnehan, 1995; Scott \& Bruce, 1994). The results indicate that our findings are less likely to be affected by common method bias.

Our data were analyzed via the maximum likelihood method with LISREL 8.5. From the original set of items we removed four items (one item that measured normative identity, utilitarian identity, self-regarding values, and other-regarding values). We followed Hair et al. (2006) and report the $\mathrm{X}^{2}$ value, together with the degrees of freedom, the CFI or TLI, and the RMSEA which provide sufficient unique information to evaluate a model. Overall, the model fit the data well as our fit indicators meet all criteria $(\mathrm{RMSEA}=0.07, \mathrm{CFI}=0.92, \mathrm{IFI}=0.92, \mathrm{NNFI}$ $=0.91$, Chi-Square: 349.41 with $\mathrm{p}<0.01$ and $\mathrm{df}=145$ ).

We further profoundly evaluated the construct validity of our measurement model by testing (a) unidimensionality of the constructs, (b) reliability, (c) convergent validity, (d) discriminant validity. Evidence of unidimensionality was found in the 'overall fit' of the measurement model and in the significance of the regression coefficients. Cronbach Alpha's of all constructs exceeded the .6 threshold (Bagozzi \& Yi, 1988) and range from 0.6 to 0.9. Convergence validity was determined by the significant size of the factor loadings. All factor loadings where well above the .5 rule of thumb (Hair et al., 2006) except for one item which was significantly related but had a loading of .4. To test the discriminant validity we compared the variance-extracted percentages for any two constructs with the square of the correlation estimate between these two constructs (Fornell \& Larcker, 1981). The variance-extracted estimates should 
be greater than the squared correlation estimate. We examined each pair of constructs in our measurement model and our data suggest this condition was met. In sum, our analysis validated the constructs in our model.

\section{Structural model}

The standardized path estimates are in line with other second order CFAs (Spreitzer, 1995). The parameter estimates indicate support for all paths in our theoretical model and superordinate construct social proclivity and economic proclivity. Social orientation, otherregarding values and normative identity are all significantly related to the second order construct social proclivity. In parallel, economic orientation, self-regarding values and utilitarian identity are all significantly related to economic proclivity. Finally, as theoretically proposed there is an inverse relation between the two second-order constructs social and economic proclivity.

\section{CONCLUSION}

Although most authors agree that social entrepreneurs are dominantly socially oriented, using economic value creation as a means to the (social) end(s), no efforts have been made to date to capture the relative importance between the social and the economic. This paper developed and validated measures capturing the social and economic proclivity of social entrepreneurs as two distinct higher order constructs. Confirmatory factor analysis shows that normative identity, social orientation and other-regarding values are significantly related to social proclivity and utilitarian identity, economic orientation and self-regarding values are significantly related to economic proclivity. Our analysis provides evidence of construct validity of the measures based on scales adapted from previous research.

Gaining understanding in how 'social' proclivity delineates from 'economic' proclivity in the context of social entrepreneurship is important for the further empirical development of the social entrepreneurship domain. First, as social entrepreneurship refers to "entrepreneurship with an embedded social purpose, through the exploitation of entrepreneurial opportunities, not being limited to a particular juridical / organizational form", using summary measures for the constructs social and economic proclivity can be useful as a starting point for better understanding how different types of social entrepreneurs actually go about trading off 'social' and 'economic' goals in practice. Second, the relative importance an enterprise attaches to the social versus the economic - in terms of overall strategic orientation - are expected to have a significant impact on the nature of the enterprise (e.g. choice / change of judicial form, type of finance, type of market, growth ambition, ...). Hence, knowing how 'social' and 'economic' an enterprise considers itself can be used as a starting point for empirical studies that attempt to explain the different contexts, business models and (social) performance levels of social entrepreneurial firms. We argue that this approach is potentially fruitful to better understand the variety of what is generally considered as 'social entrepreneurship'. In this respect, the proposed measures are not to be used in a normative sense, i.e. to decide what is socially entrepreneurial and what is not - but to disentangle the relative importance between the social and the economic. As Peredo and McLean (2006: 64) stated: "There is no exact way of fixing the border below which the importance of social goals fails to qualify something as social entrepreneurship."

\section{REFERENCES AVAILABLE FROM THE AUTHORS}

